\title{
Endothelin and Diabetic Complications: a Brain-Centric View
}

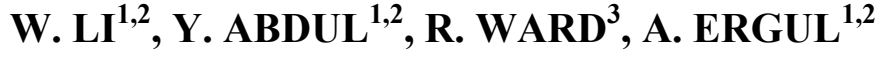 \\ ${ }^{1}$ Charlie Norwood Veterans Affairs Medical Center, Augusta, Georgia, USA, \\ ${ }^{2}$ Department of Physiology, Augusta University, Augusta, Georgia, USA, ${ }^{3}$ Department of \\ Neuroscience and Regenerative Medicine, Augusta University, Augusta, Georgia, USA
}

Received December 11, 2017

Accepted February 9, 2018

\begin{abstract}
Summary
The global epidemic of diabetes is of significant concern. Diabetes associated vascular disease signifies the principal cause of morbidity and mortality in diabetic patients. It is also the most rapidly increasing risk factor for cognitive impairment, a silent disease that causes loss of creativity, productivity, and quality of life. Small vessel disease in the cerebral vasculature plays a major role in the pathogenesis of cognitive impairment in diabetes. Endothelin system, including endothelin-1 (ET-1) and the receptors $\left(\mathrm{ET}_{\mathrm{A}}\right.$ and $\left.\mathrm{ET}_{\mathrm{B}}\right)$, is a likely candidate that may be involved in many aspects of the diabetes cerebrovascular disease. In this review, we took a brain-centric approach and discussed the role of the ET system in cerebrovascular and cognitive dysfunction in diabetes.
\end{abstract}

\section{Key words}

Endothelin • Cognitive impairment • Cerebrovascular dysfunction - Neurovascular unit • Diabetes

\section{Corresponding author}

A. Ergul, Department of Physiology, Augusta University, 1120 15th Street CA-2094, Augusta, Georgia 30912, USA. Fax: 706.721.7299. E-mail: aergul@augusta.edu

\section{Introduction}

According to International Diabetes Federation, 425 million people had diabetes worldwide in 2017 and this is expected to rise up to 629 million by 2045 (IDF 2017). Given that cardiovascular complications of diabetes are the leading cause of morbidity and mortality associated with the disease, this epidemic has a huge burden on global health. As such, microvascular (nephropathy, retinopathy, and neuropathy) and macrovascular (heart disease, stroke, and peripheral arterial disease) complications of diabetes represent intense areas of research. It is increasingly recognized that cognitive dysfunction is an emerging complication that should be added to the diabetic complications list (Simo et al. 2017). Small vessel disease, involving both structural and functional changes in the cerebral microvasculature, plays a major role in the pathogenesis and progression of cognitive dysfunction in diabetes (Blair et al. 2017, Gorelick et al. 2017). While the mechanisms are multifactorial, endothelial dysfunction, reduced cerebral blood flow (CBF) and hypoperfusion is believed to precede the negative changes in the cognitive function observed in both patients and experimental models.

Endothelium is an early target in diabetes and cerebrovascular dysfunction resulting from an imbalance of endothelium-derived vasoconstrictor and vasodilator substances can contribute to the early decrease in $\mathrm{CBF}$ which could trigger the neuroinflammation and oxidative/nitrative stress. Endothelin-1 (ET-1), a potent vasoconstrictor with proliferative, profibrotic, prooxidative and proinflammatory properties, is a likely candidate that may be involved in many facets of diabetic cerebrovascular disease (Daulatzai 2017, Faraco et al. 2013). It has been suggested that high glucose level as seen in diabetes up-regulates the ET-1 system in the endothelial cells through many different pathways (Chiu et al. 2008, Li et al. 2013, Manea et al. 2013, Wu et al. 2010). For example, early studies reported that high glucose-mediated disruption of endothelial barrier 
function involves upregulation of ET-1 (Chen et al. 2000). More recently, miR-1 has been reported to regulate ET-1 expression under high glucose conditions (Feng et al. 2014, Feng et al. 2012). It has to be noted that diabetes-mediated increase in ET-1 production may not be limited to endothelial cells. Vascular smooth muscle cells (VSMC) (Banes-Berceli et al. 2005) and macrophages (Takahashi et al. 2015) are known to produce ET-1, especially under high glucose conditions. Indeed, recent studies suggested that ET-1 contributes to pathological cerebral vascularization and early cerebrovascular dysfunction in models of diabetes that present with cognitive dysfunction (Abdelsaid et al. 2014a, Abdelsaid et al. 2014b, Kelly-Cobbs et al. 2011b, Niedowicz et al. 2014). Glycemic control reduces activation of the ET system, prevents and even reverses pathological changes observed in the cerebral circulation (Kelly-Cobbs et al. 2011a). While some studies reported that $\mathrm{ET}_{\mathrm{A}}$ antagonist or dual blockade of ET receptors prevent cognitive decline in different disease models (Freeman et al. 2016, Singh et al. 2014, Singh et al. 2017), other studies showed $\mathrm{ET}_{\mathrm{B}}$ receptor stimulation may be beneficial in prevention of cognitive impairment (Briyal et al. 2015, Briyal et al. 2014). In a culture system, ET-1 appears to be protective of hippocampal neurons grown in a diabetes-mimicking environment (Ward et al. 2016). Thus, our current understanding of the role of ET-1 in diabetic complications will be reviewed with a focus on the cerebrovascular and cognitive dysfunction.

\section{Cerebral perfusion and brain health}

Adequate cerebral perfusion is essential for brain function, an organ that has high metabolic demands but minimal or almost no energy stores (Attwell et al. 2010, Iadecola et al. 2010). Blood delivers nutrients such as glucose and oxygen while removing metabolites. Hence, tight regulatory mechanisms operate to ensure optimum cerebral perfusion, which involve cerebrovascular autoregulation, neurovascular coupling and ligandmediated vasoreactivity. These properties of the cerebral circulation require orchestrated action of the components of the neurovascular unit comprised of neurons, glial cells, pericytes, vascular endothelial and SMCs, as well as perivascular cells and cerebrovascular matrix. In this complex system, endothelial cells regulate microvascular blood flow and integrity by releasing vasoactive agents such as ET-1 and nitric oxide (NO)

\section{Diabetes, cerebrovascular dysfunction and ET-1}

In this section, we will review the role of ET-1 on four mechanisms involved in regulation of cerebrovascular physiology, namely cerebral autoregulation, myogenic tone, neurovascular coupling, and ligand-mediated vasoreactivity in this order.

\section{Cerebral autoregulation and myogenic tone}

Cerebral autoregulation is one of the well-developed mechanisms in the brain to protect it from fluctuations in perfusion pressure (Cipolla 2016). While several mechanisms contribute to the process of cerebral autoregulation, the most prominent one is the myogenic response, which describes the ability of SMCs to react to changes in blood pressure in order to keep blood flow constant. SMCs usually contract as result of stretching, which is due to an increase in blood pressure, and dilate upon blood pressure reduction. As previously reviewed, diabetes affects myogenic tone emphasizing the direct effects of ET-1 on SMC contractility (Ergul et al. 2012). Although it is not in a diabetic model, ET-1-mediated peroxynitrite formation has been shown to augment baseline tone of penetrating arterioles of the brain. While in most models (Cipolla et al. 2013), diabetes increases the mygenic tone, this appears to be age-dependent (Kelly-Cobbs et al. 2011a).

ET-1 contributes to dysregulation of myogenic response and tone in diabetes. Dumont et al. (2003) demonstrated that diabetic rats develop a greater tone and treatment with bosentan, a dual antagonist that blocks both ET receptor subtypes, restores myogenic tone to control levels. We have shown that middle cerebral arteries (MCA) from spontaneously diabetic GotoKakizaki (GK) rats exhibit increased myogenic tone in the early disease course (10 weeks of age) but later (18 weeks of age) show decreased tone development (Kelly-Cobbs et al. 2011a, Kelly-Cobbs et al. 2012). Glycemic control with metformin started at the onset of diabetes prevented the decreased ability to develop tone and also restored the increased ET-1 levels in this model (Kelly-Cobbs et al. 2011a). Another study reported that bosentan treatment started at 18 weeks after the vascular disease was established could reverse the myogenic dysfunction in aged diabetic rats (Abdelsaid et al. 2014b). 


\section{Neurovascular coupling}

While cerebral autoregulation contributes to maintaining constant blood flow to the brain despite changes in cerebral perfusion pressure, fine tuning of the delivery of blood where it is needed is achieved by bidirectional communication between neurons and vasculature. This interaction is known as neurovascular coupling and results in an increase in CBF, a response referred as functional hyperemia. Vessels around the firing neurons dilate in response to the signals they receive and match blood flow to the increased metabolic demand of neurons. Our knowledge of neurovascular (un)coupling in diabetes, let alone the role of ET-1 in this process, is very limited. One study found that retinal arteriole dilation in response to light stimulation is reduced in type 1 diabetic rats compared to control (Mishra et al. 2010). Another study reported impaired neurovascular coupling in the cerebral vasculature of type 1 diabetic rats (Vetri et al. 2017, Vetri et al. 2012). In type 2 diabetes, impaired functional hyperemia has been reported in the GK rats, which also display increased myogenic tone and activation of the ET system in the cerebrovasculature (Harris et al. 2005, Kelly-Cobbs et al. 2011b, Kelly-Cobbs et al. 2012). Studies in other disease models such as hypertension showed that ET-1 is involved in neurovascular uncoupling, but a direct role in diabetes remains to be established (Capone et al. 2012a, Capone et al. 2012b).

\section{Agonist-induced vasoreactivity}

Endothelium-dependent relaxation of basilar arteries but not mesenteric arteries is impaired in GK rats, a lean model of type 2 diabetes that presents with moderate hyperglycemia and insulin resistance without obesity (Sachidanandam et al. 2006). As discussed below, this model also displays hyperreactivity to ET-1 as evidenced by greater contraction. Blockade of $\mathrm{ET}_{\mathrm{A}}$ receptor improves relaxation but $\mathrm{ET}_{\mathrm{B}}$ selective blockade with A-192621 causes paradoxical constriction of basilar arteries (Harris et al. 2008). Intriguingly, dual blockade of both $\mathrm{ET}_{\mathrm{A}}$ and $\mathrm{ET}_{\mathrm{B}}$ receptors with bosentan improves the maximum relaxation response ( $\mathrm{Li}$ et al. 2011). A recent study demonstrated that oral hypoglycemic linagliptin improves the ET-1-mediated cerebrovascular dysfunction observed in the GK model through a reduction in ET-1 plasma levels and reduced cerebrovascular hyperreactivity (Hardigan et al. 2016a, Hardigan et al. 2016c). This effect is potentially a result of linagliptin causing a decrease in endothelial toll like receptor 2 (TLR2) expression and a subsequent increase in NO bioavailability (Hardigan et al. 2016a, Hardigan et al. 2016c). Interestingly, linagliptin did not correct hyperglycemia suggesting that these effects are blood glucose-independent.

Contractile response to ET-1 is augmented in the rat and rabbit basilar arteries of type 1 diabetic rats, respectively (Alabadi et al. 2004, Matsumoto et al. 2004). Arrick and coworkers showed that type 1 diabetes impairs endothelium-dependent vasorelaxation by dysregulation of both eNOS and nNOS in an oxidative stress manner (Alomar et al. 2016, Arrick et al. 2010, Arrick et al. 2007b, Arrick et al. 2007a, Arrick et al. 2011, Mayhan et al. 2017, Mayhan et al. 2011). Furthermore, the same group, using a cranial window approach to study pial vascular responses, reported that local $\mathrm{ET}_{\mathrm{A}}$ blockade by $\mathrm{BQ}-123$ restored the impaired eNOS- and nNOS-dependent vasodilation (Arrick et al. 2010). This finding appeared to be specific for NOS-dependent reactivity since response to nitroglycerin were not altered by BQ-123. Additionally, the production of superoxide anion was increased from parietal cortex tissue in diabetic rats and $\mathrm{BQ}-123$ inhibited this basal superoxide production. A recent study showed that overexpression of ET-1 in the endothelium exacerbates endothelial dysfunction in resistance arteries in diabetes via excessive generation of free radicals. This detrimental effect involved multiple mechanisms including decreased eNOS expression, increased vascular superoxide production and attenuation of the antioxidant capacity as indicated by an inability to upregulate superoxide dismutase expression (Idris-Khodja et al. 2016). Similar findings have been reported in the ophthalmic circulation (Granstam et al. 2011). While no study explored the mechanistic link between ET-1-mediated reactive species generation and cognitive dysfunction in metabolic diseases, a recent review summarizes the role of oxidative stress in cognitive dysfunction in general (Grochowski et al. 2018). Collectively, these studies strongly suggest that ET-1 is a significant contributor to cerebrovascular dysfunction in diabetes via generation of reactive oxygen and nitrogen species.

In summary, activation of the ET system in the cerebrovasculature promotes vascular dysfunction at multiple levels and contributes to dysregulation of CBF in diabetes. 
Diabetes, cerebrovascular remodeling/neovascularization and ET-1

Changes in cerebrovascular structure are equally important for proper brain function in diabetes. While cerebrovascular restructuring is beneficial to maintain physiological integrity in health, pathological remodeling can occur in disease settings such as diabetes and affect both cerebrovascular function and integrity of the blood brain barrier (BBB) leading to increased permeability.

\section{Cerebrovascular remodeling}

Type 2 diabetic GK rats develop significant cerebrovascular remodeling of middle cerebral arteries characterized by reduced lumen diameter, increased wall-to-lumen ratio and wall thickness in a relatively short time after the onset of diabetes (Harris et al. 2005). This remodeling causes an increase in the MCA wall stiffness that is associated with an increased expression of extracellular matrix proteins and an increase in the activity of matrix metalloproteases (MMPs) (Harris et al. 2005, Li et al. 2010). A significant decrease in the cerebral perfusion came in parallel with the increase in media-to-lumen ratio (Kelly-Cobbs et al. 2012). The role of ET-1 in this cerebrovascular remodeling response appears to be quite complex. While selective $\mathrm{ET}_{\mathrm{A}}$ (atrasentan) or $\mathrm{ET}_{\mathrm{B}}$ receptor (A192621) blockade partially blocks remodeling, dual antagonism with bosentan completely attenuates this response (Harris et al. 2005, Kelly-Cobbs et al. 2011b). The results with selective $\mathrm{ET}_{\mathrm{B}}$ receptor blockade were surprising. Given that genetic or pharmacological inhibition of $\mathrm{ET}_{\mathrm{B}}$ receptors worsen vascular remodeling in a wire injury model (Murakoshi et al. 2002), it was originally hypothesized that diabetes decreases protective endothelial $\mathrm{ET}_{\mathrm{B}}$ receptors contributing to vascular remodeling and antagonism of this receptor exacerbates the changes in the vascular structure. Diabetes did not influence endothelial $\mathrm{ET}_{\mathrm{B}}$ receptors but $\mathrm{ET}_{\mathrm{A}}$ and $\mathrm{ET}_{\mathrm{B}}$ receptors on smooth muscles were increased. This was prevented by chronic bosentan treatment. On the other hand, A192621 treatment augmented remodeling in control animals indicating a physiological protective role for the $\mathrm{ET}_{\mathrm{B}}$ receptor subtype (Kelly-Cobbs et al. 2011b). The finding that bosentan treatment prevents the changes in ET receptor profile suggests that ET-1 has a positive feedback on the expression of its receptors in the cerebrovasculature, underscoring the fact that the ET receptor antagonism may yield different results in healthy and diseased states.

While these early studies suggested that ET receptor antagonism can be an effective prevention strategy, follow up studies showed that adverse remodeling of middle cerebral arteries can be reversed by glycemic control with metformin or ET receptor antagonism with bosentan, suggesting that ET system can be therapeutically targeted as well (Abdelsaid et al. 2014a). Furthermore, treatment with a relatively new class of oral hypoglycemic linagliptin is effective in reversing established pathological cerebrovascular remodeling in the GK model (Yasir et al. 2016). As briefly discussed above, this treatment did not lower blood glucose in this model. In vitro studies showed that linagliptin prevented the ET-1-mediated increase in SMC $\mathrm{ET}_{\mathrm{A}}$ receptors under high glucose conditions, suggesting that attenuation of the ET system could be a pleiotropic effect of linagliptin that provides vascular protection (Yasir et al. 2016).

\section{Cerebral neovascularization}

Our understanding of the impact of diabetes on neovascularization mostly came from peripheral and retinal circulation. While diabetes is known to impair angiogenesis and collateral formation in the heart and peripheral circulation, in the retinal circulation, pathological angiogenesis occurs leading to diabetic retinopathy. In the brain, diabetes causes microangiopathy similar to the retina. Diabetes causes increased, yet dysfunctional, neovascularization in the cortex and striatum of type 2 diabetic GK rats (Prakash et al. 2013b, Prakash et al. 2012). Vascular density, volume and surface area are increased but associated with poor vessel wall maturity as indicated by reduced pericytes and increased permeability. On the other hand, another group reported decreased vascularization and capillary branching in the dentate gyrus of the hippocampus, an area associated with memory and learning processes, in GK rats (Beauquis et al. 2010). It is also possible that there are differences in the angiogenic response in very specialized areas of the brain. Comparative studies with the $\mathrm{db} / \mathrm{db}$ mouse model and high fat diet/low dose streptozotosin-induced rat model of type 2 diabetes demonstrated similar findings to the GK model suggesting that pathological vascularization is a common finding in diabetes (Prakash et al. 2013a, Qu et al. 2014).

ET-1 contributes to tumor angiogenesis, another form of pathological angiogenesis characterized by irregular vascularization, via the activation of hypoxia- 
inducible factor and VEGF-A (Garrafa et al. 2012, Rosano et al. 2013, Spinella et al. 2010). A recent study showed that dual ET receptor blockade with bosentan reverses pathological cerebral neovascularization in GK rats with established cerebrovascular disease and improved BBB integrity (Abdelsaid et al. 2014a). A follow-up study reported that treatment with oral hypoglycemic linagliptin also reduces cerebral neovascularization as well as formation of string vessels, a marker of vascular degeneration. Moreover, linagliptin normalizes the augmented angiogenic properties of brain microvascular endothelial cells isolated from diabetic animals and bosentan blocks this response. While linagliptin significantly decreases ET-1 levels, it increases $\mathrm{ET}_{\mathrm{B}}$ receptors (Abdelsaid et al. 2016). $\mathrm{ET}_{\mathrm{A}}$ receptor antagonism has been shown to reduce string vessels and neuronal death in a diabetic retinopathy model providing additional evidence that ET receptor blockade is neurovascular protective in diabetes (Chou et al. 2014).

Collectively, these studies suggest that ET-1 negatively impacts cerebrovascular structure, density, and integrity in diabetes. All these changes can contribute to the development of neuroinflammation and neurovascular degeneration in cognitive impairment by reducing blood flow and increasing BBB permeability.

\section{Diabetes, cognitive impairment and ET-1}

Individuals with diabetes have been shown to have changes in brain structure and cognitive function (Franc et al. 2011, Stiles et al. 2010). Yet, cognitive impairment remains to be one of the less understood and less studied complications of diabetes. As recently reviewed, there may be differences in the pathogenesis of the diseases between type 1 and type 2 diabetes (Hardigan et al. 2016b, Moheet et al. 2015, Riederer et al. 2017). Readers are referred to these reviews on diabetes and cognitive impairment in general. In this review, we will summarize what is known about the role of the ET system in cognitive impairment and especially in diabetes.

ET-1 has been implicated to contribute to cognitive deficits in various models of cognitive impairment and dementia (Daulatzai 2017). In a series of studies, Palmer and colleagues demonstrated that ET-1 and endothelin converting enzyme (ECE-1 and 2) activities to be upregulated in the brains of patients with Alzheimer's Disease (AD) (Palmer et al. 2011, Palmer et al. 2012, Palmer et al. 2013). ET-1-mediated vascular dysfunction and ensuing cognitive deficits have been reported in transforming growth factor- $\beta 1$ transgenic mice that mimic the vascular pathology of $\mathrm{AD}$ (Papadopoulos et al. 2010, Tong et al. 2015) as well as under water deprivation conditions (Faraco et al. 2013, Faraco et al. 2014). On a sweet note, flavonol-rich dark cocoa has been shown to decrease plasma endothelin-1 and improve cognition in urban children (CalderonGarciduenas et al. 2013).

A causal role of ET-1 in cognitive impairment in different disease models has been tested by using selective or dual ET receptor blockers. Interestingly, Freeman and colleagues showed that ET-1 mediates brain microvascular dysfunction leading to long-term cognitive impairment in a model of experimental cerebral malaria (Freeman et al. 2016). $\mathrm{ET}_{\mathrm{A}}$ receptor antagonists $\mathrm{BQ} 123$ or BMS182874 prevented cognitive dysfunction in a model of $A D$ in which disease is induced by injection of amyloid $B(A \beta 1-40)$ in the lateral cerebral ventricles (Briyal et al. 2011). However, nonspecific $\mathrm{ET}_{\mathrm{A}} / \mathrm{ET}_{\mathrm{B}}$ receptor antagonist TAK-044 had no effect in this model. On the other hand, treatment with bosentan improved learning and memory as well as mitochondrial and carotid artery endothelial function in a similar yet slightly different model of AD. In this study, cognitive impairment was induced by combined administration of single intracerebroventricular infusion of $A \beta$ and chronic oral administration of L-methionine resulting in hyperhomocysteinemia (Singh et al. 2017). The same group also reported that bosentan improves cognition in a two-kidney one-clip model of hypertension. It has to be noted that, in this study, ET receptor antagonism also attenuated the increase in mean arterial blood pressure (Singh et al. 2016). In contrast to these studies, Briyal et al. (2015) reported that stimulation of $\mathrm{ET}_{\mathrm{B}}$ receptors with ILR1620 decreases the progression of AD. This particular study used a model in which cognitive deficits were induced by A $\beta 1-40$ injection into the brain. IRL1620 and $\mathrm{ET}_{\mathrm{B}}$ receptor antagonist $\mathrm{BQ788}$ were also administered locally by stereotactic injection.

In the context of diabetes, $\mathrm{ET}_{\mathrm{B}}$ receptor activation has been reported to prevent cerebral oxidative stress and improve cognitive function in type 1 diabetic rats that received intracerebroventricular $\mathrm{A} \beta 1-40$ injections along with IRL1620 and BQ788 (Briyal et al. 2014). Behavioral and cognitive outcomes were determined two weeks after the administration of A $\beta 1-40$ and drug. On the other hand, Singh et al. (2014) assessed 
cognitive function two months after the onset of type 1 diabetes and treated the animals with bosentan or donepezil during the second month. This study demonstrated that bosentan improved endothelial function and cognitive behavior significantly although donezepil was more effective (Singh et al. 2014).

\section{Integration}

This review on the role of the ET system in diabetic complications focuses on the central nervous system with an emphasis on cognitive impairment. While studies described above demonstrate conflicting conclusions with regard to the use of ET receptor antagonism or $\mathrm{ET}_{\mathrm{B}}$ activation in the prevention or treatment of cognitive impairment in preclinical models, they also offer an opportunity to evaluate the role of ET-1 as well as its isoforms and receptors on memory and cognitive function in the context of 1) neurovascular unit, and 2) models of diabetes and cognitive impairment.

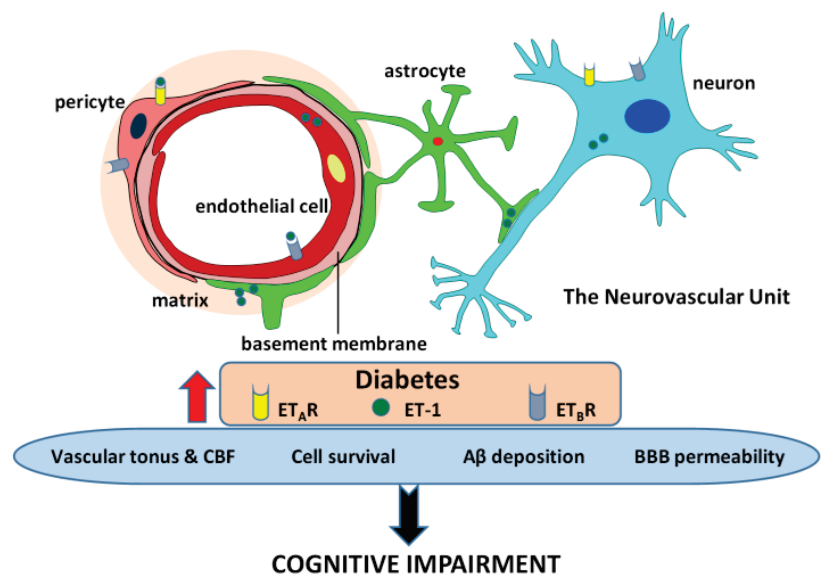

Fig. 1. The ET system is present in all components of the neurovascular unit and may contribute to the development of cognitive impairment in diabetes by increasing the cerebrovascular tone and the reduction of cerebral blood flow, disrupting blood brain barrier integrity, impairing cell survival, and causing $A \beta$ deposition.

When we approach the issue from neurovascular unit perspective, we need to think about neurons, astrocytes, pericytes, vascular endothelial and SMCs as well as perivascular cells and cerebrovascular matrix (Fig. 1). For example, some studies showed that $\mathrm{ET}_{\mathrm{A}}$ or dual $\mathrm{ET}_{\mathrm{A}} / \mathrm{ET}_{\mathrm{B}}$ receptor antagonism is neuroprotective and improves outcomes after ischemia reperfusion injury of the brain (Dawson et al. 1999, Gupta et al. 2005, Matsuo et al. 2001, Zhang et al. 2008). Moreover, endothelial cell specific overexpression of ET-1 worsened cerebral damage (Leung et al. 2009) and ET-1 induced degeneration of cultured motor neurons (Ward et al. 2016). On the other hand, some studies suggested that the ET receptor blockade exacerbates brain infarction (Chuquet et al. 2002) and ET-1 improves neuronal survival in cell culture models (Leung et al. 2009, Ward et al. 2016).

In astrocytes, targeted overexpression of ET-1 exacerbates ischemia reperfusion injury of the brain (Yeung et al. 2009) and contributes to dementia associated with ischemic stroke by exaggerating astrocyte-derived amyloid secretion (Hung et al. 2015). An earlier study showed that glial-derived ET-1 contributes to delayed neuronal death in the hippocampus (Yamashita et al. 2000). Readers are referred to a recent review article for further reading, which highlighted astrocytes as the neglected co-star in cognitive impairment and emphasized ET- 1 and $\mathrm{A} \beta$ interactions (Jo et al. 2014).

From a vascular perspective, there is no doubt that $\mathrm{ET}_{\mathrm{A}}$ receptors mediate vasoconstriction in many vascular beds. In the cerebral circulation, especially under hypoxic conditions, vascular smooth muscle cell $\mathrm{ET}_{\mathrm{B}}$ receptors are upregulated and mediate vasoconstriction as demonstrated by Kelly-Cobbs et al. (2011b) in a diabetes model as well as many studies by the Edvinsson laboratory (Henriksson et al. 2003, Stenman et al. 2002). A recent study by this group provided evidence for the first time that contractility of intraparenchymal arterioles, bottleneck of cerebral perfusion, is augmented after global cerebral ischemia in an ET-1 and $\mathrm{ET}_{\mathrm{B}}$ receptor-dependent manner contributing delayed cerebral hypoperfusion (Spray et al. 2017). Early studies showed that ET-1 by binding to $\mathrm{ET}_{\mathrm{A}}$ receptors regulates the arrangement of actin cytoskeleton in pericytes, contractile cells at the capillary level, and upregulation of both receptors contribute to disturbed microvascular autoregulation and sustained reduction of CBF following trauma to the brain (Dehouck et al. 1997, Kallakuri et al. 2007).

Collectively, studies summarized above show that the ET system is present in all components of the neurovascular unit. The interaction(s) between these cellular compartments and potential contribution(s) in regulation of cognition are quite complex. Moreover, diabetes impacts structure and function of the neurovascular unit significantly. As discussed above, there are only two studies that directly tested the role of ET receptors in cognitive impairment in diabetes. Both of 
these studies used type 1 model of diabetes. While one of the studies looked at the direct effect of diabetes, the other study accelerated the development of cognitive deficits by $\mathrm{A} \beta$ injection, a model of $\mathrm{AD}$. Thus, future studies are critically needed to investigate either the spontaneous development of cognitive deficits over time and/or in combination with cerebral hypoperfusion, the most common model of vascular cognitive impairment in type 2 diabetes models. We need pharmacological tools to manipulate the $\mathrm{ET}_{\mathrm{B}}$ receptors. The limited availability of $\mathrm{ET}_{\mathrm{B}}$ selective antagonists limited the progress in this area. At the cellular level, the specific role of the ET system in different members of the neurovascular unit can be teased out by cell specific knock-out or overexpression studies in the diabetic background. Equally important, we need to incorporate female animals into the experimental design. Most, if not all, of the studies highlighted in this review were conducted using male animals. It is encouraging that the cognitive outcomes will be assessed as a secondary endpoint in the ongoing Study Of Diabetic Nephropathy With Atrasentan (SONAR).

\section{Conflict of Interest}

There is no conflict of interest.

\section{Acknowledgements}

AE is a Research Career Scientist at the Charlie Norwood Veterans Affairs Medical Center in Augusta, Georgia. This work was supported in part by a Veterans Affairs (VA) Merit Award (BX000347), VA Research Career Scientist Award, and National Institutes of Health (NIH) awards (R01NS083559, PO1HL128207) to AE, American Heart Association Predoctoral Fellowship to RW (17PRE33660400), and the Pilot \& Feasibility Grant (NIDDK Diabetic Complications Consortium grants DK076169 and DK115255) to WL. The contents do not represent the views of the Department of Veterans Affairs or the US Government.

\section{References}

ABDELSAID M, KACZMAREK J, COUCHA M, ERGUL A: Dual endothelin receptor antagonism with bosentan reverses established vascular remodeling and dysfunctional angiogenesis in diabetic rats: relevance to glycemic control. Life Sci 118: 268-273, 2014a.

ABDELSAID M, MA H, COUCHA M, ERGUL A: Late dual endothelin receptor blockade with bosentan restores impaired cerebrovascular function in diabetes. Life Sci 118: 263-267, $2014 \mathrm{~b}$.

ABDELSAID M, WILLIAMS R, HARDIGAN T, ERGUL A: Linagliptin attenuates diabetes-induced cerebral pathological neovascularization in a blood glucose-independent manner: potential role of ET-1. Life Sci 159: 83-89, 2016.

ALABADI JA, MIRANDA FJ, LLORENS S, CENTENO JM, MARRACHELLI VG, ALBORCH E: Mechanisms underlying diabetes enhancement of endothelin-1-induced contraction in rabbit basilar artery. Eur J Pharmacol 486: $289-296,2004$.

ALOMAR F, SINGH J, JANG HS, ROZANZKI GJ, SHAO CH, PADANILAM BJ, MAYHAN WG, BIDASEE KR: Smooth muscle-generated methylglyoxal impairs endothelial cell-mediated vasodilatation of cerebral microvessels in type 1 diabetic rats. Br J Pharmacol 173: 3307-3326, 2016.

ARRICK DM, MAYHAN WG: Inhibition of endothelin-1 receptors improves impaired nitric oxide synthase-dependent dilation of cerebral arterioles in type-1 diabetic rats. Microcirculation 17: 439-446, 2010.

ARRICK DM, SHARPE GM, SUN H, MAYHAN WG: nNOS-dependent reactivity of cerebral arterioles in Type 1 diabetes. Brain Res 1184: 365-371, 2007a.

ARRICK DM, SHARPE GM, SUN H, MAYHAN WG: Diabetes-induced cerebrovascular dysfunction: role of poly(ADP-ribose) polymerase. Microvasc Res 73: 1-6, $2007 \mathrm{~b}$.

ARRICK DM, SUN H, PATEL KP, MAYHAN WG: Chronic resveratrol treatment restores vascular responsiveness of cerebral arterioles in type 1 diabetic rats. Am J Physiol Heart Circ Physiol 301: H696-H703, 2011.

ATTWELL D, BUCHAN AM, CHARPAK S, LAURITZEN M, MACVICAR BA, NEWMAN EA: Glial and neuronal control of brain blood flow. Nature 468: 232-243, 2010. 
BANES-BERCELI AK, OGOBI S, TAWFIK A, PATEL B, SHIRLEY A, POLLOCK DM, FULTON D, MARRERO MB: Endothelin-1 activation of JAK2 in vascular smooth muscle cells involves NAD(P)H oxidase-derived reactive oxygen species. Vascul Pharmacol 43: 310-319, 2005.

BEAUQUIS J, HOMO-DELARCHE F, GIROIX MH, EHSES J, COULAUD J, ROIG P, PORTHA B, DE NICOLA AF, SARAVIA F: Hippocampal neurovascular and hypothalamic-pituitary-adrenal axis alterations in spontaneously type 2 diabetic GK rats. Exp Neurol 222: 125-134, 2010.

BLAIR GW, APPLETON JP, LAW ZK, DOUBAL F, FLAHERTY K, DOOLEY R, SHULER K, RICHARDSON C, HAMILTON I, SHI Y, STRINGER M, BOYD J, THRIPPLETON MJ, SPRIGG N, BATH PM, WARDLAW JM: Preventing cognitive decline and dementia from cerebral small vessel disease: the LACI-1 Trial. Protocol and statistical analysis plan of a phase IIa dose escalation trial testing tolerability, safety and effect on intermediary endpoints of isosorbide mononitrate and cilostazol, separately and in combination. Int J Stroke: 1747493017731947,2017

BRIYAL S, NGUYEN C, LEONARD M, GULATI A: Stimulation of endothelin B receptors by IRL-1620 decreases the progression of Alzheimer's disease. Neuroscience 301: 1-11, 2015.

BRIYAL S, PHILIP T, GULATI A: Endothelin-A receptor antagonists prevent amyloid-beta-induced increase in ETA receptor expression, oxidative stress, and cognitive impairment. J Alzheimers Dis 23: 491-503, 2011.

BRIYAL S, SHEPARD C, GULATI A: Endothelin receptor type B agonist, IRL-1620, prevents beta amyloid (Abeta) induced oxidative stress and cognitive impairment in normal and diabetic rats. Pharmacol Biochem Behav 120: 65-72, 2014.

CALDERON-GARCIDUENAS L, MORA-TISCARENO A, FRANCO-LIRA M, CROSS JV, ENGLE R, ARAGONFLORES M, GOMEZ-GARZA G, JEWELLS V, MEDINA-CORTINA H, SOLORIO E, CHAO CK, ZHU H, MUKHERJEE PS, FERREIRA-AZEVEDO L, TORRES-JARDON R, D'ANGIULLI A: Flavonol-rich dark cocoa significantly decreases plasma endothelin-1 and improves cognition in urban children. Front Pharmacol 4: 104, 2013.

CAPONE C, FARACO G, COLEMAN C, YOUNG CN, PICKEL VM, ANRATHER J, DAVISSON RL, IADECOLA C: Endothelin 1-dependent neurovascular dysfunction in chronic intermittent hypoxia. Hypertension 60: 106-113, 2012a.

CAPONE C, FARACO G, PETERSON JR, COLEMAN C, ANRATHER J, MILNER TA, PICKEL VM, DAVISSON RL, IADECOLA C: Central cardiovascular circuits contribute to the neurovascular dysfunction in angiotensin II hypertension. J Neurosci 32: 4878-4886, 2012 b.

CHEN S, APOSTOLOVA MD, CHERIAN MG, CHAKRABARTI S: Interaction of endothelin-1 with vasoactive factors in mediating glucose-induced increased permeability in endothelial cells. Lab Invest 80: 1311-1321, 2000.

CHIU J, XU BY, CHEN S, FENG B, CHAKRABARTI S: Oxidative stress-induced, poly(ADP-ribose) polymerasedependent upregulation of ET-1 expression in chronic diabetic complications. Can J Physiol Pharmacol 86: 365-372, 2008.

CHOU J, ROLLINS S, FAWZI AA: Role of endothelial cell and pericyte dysfunction in diabetic retinopathy: review of techniques in rodent models. Adv Exp Med Biol 801: 669-675, 2014.

CHUQUET J, BENCHENANE K, TOUTAIN J, MACKENZIE ET, ROUSSEL S, TOUZANI O: Selective blockade of endothelin-B receptors exacerbates ischemic brain damage in the rat. Stroke 33: 3019-3025, 2002.

CIPOLLA MJ: The Cerebral Circulation. Morgan and Claypool Life Sciences, San Rafael, CA, 2016.

CIPOLLA MJ, SWEET JG, GOKINA NI, WHITE SL, NELSON MT: Mechanisms of enhanced basal tone of brain parenchymal arterioles during early postischemic reperfusion: role of ET-1-induced peroxynitrite generation. J Cereb Blood Flow Metab 33: 1486-1492, 2013.

DAULATZAI MA: Cerebral hypoperfusion and glucose hypometabolism: key pathophysiological modulators promote neurodegeneration, cognitive impairment, and Alzheimer's disease. J Neurosci Res 95: 943-972, 2017.

DAWSON DA, SUGANO H, MCCARRON RM, HALLENBECK JM, SPATZ M: Endothelin receptor antagonist preserves microvascular perfusion and reduces ischemic brain damage following permanent focal ischemia. Neurochem Res 24: 1499-1505, 1999. 
DEHOUCK MP, VIGNE P, TORPIER G, BREITTMAYER JP, CECCHELLI R, FRELIN C: Endothelin-1 as a mediator of endothelial cell-pericyte interactions in bovine brain capillaries. J Cereb Blood Flow Metab 17 : 464-469, 1997.

DUMONT AS, DUMONT RJ, MCNEILL JH, KASSELL NF, SUTHERLAND GR, VERMA S: Chronic endothelin antagonism restores cerebrovascular function in diabetes. Neurosurgery 52: 653-660, 2003.

ERGUL A, KELLY-COBBS A, ABDALLA M, FAGAN SC: Cerebrovascular complications of diabetes: focus on stroke. Endocr Metab Immune Disord Drug Targets 12: 148-158, 2012.

FARACO G, MORAGA A, MOORE J, ANRATHER J, PICKEL VM, IADECOLA C: Circulating endothelin-1 alters critical mechanisms regulating cerebral microcirculation. Hypertension 62: 759-766, 2013.

FARACO G, WIJASA TS, PARK L, MOORE J, ANRATHER J, IADECOLA C: Water deprivation induces neurovascular and cognitive dysfunction through vasopressin-induced oxidative stress. J Cereb Blood Flow Metab 34: 852-860, 2014.

FENG B, CAO Y, CHEN S, RUIZ M, CHAKRABARTI S: miRNA-1 regulates endothelin-1 in diabetes. Life Sci 98: 18-23, 2014.

FENG B, CHAKRABARTI S: miR-320 regulates glucose-induced gene expression in diabetes. ISRN Endocrinol 2012: $549875,2012$.

FRANC DT, KODL CT, MUELLER BA, MUETZEL RL, LIM KO, SEAQUIST ER: High connectivity between reduced cortical thickness and disrupted white matter tracts in long-standing type 1 diabetes. Diabetes 60: 315-319, 2011.

FREEMAN BD, MARTINS YC, AKIDE-NDUNGE OB, BRUNO FP, WANG H, TANOWITZ HB, SPRAY DC, DESRUISSEAUX MS: Endothelin-1 mediates brain microvascular dysfunction leading to long-term cognitive impairment in a model of experimental cerebral malaria. PLoS Pathog 12: e1005477, 2016.

GARRAFA E, CAPRARA V, DI CASTRO V, ROSANO L, BAGNATO A, SPINELLA F: Endothelin-1 cooperates with hypoxia to induce vascular-like structures through vascular endothelial growth factor-C, $-\mathrm{D}$ and $-\mathrm{A}$ in lymphatic endothelial cells. Life Sci 91: 638-643, 2012.

GORELICK PB, FURIE KL, IADECOLA C, SMITH EE, WADDY SP, LLOYD-JONES DM, BAE HJ, BAUMAN MA, DICHGANS M, DUNCAN PW, GIRGUS M, HOWARD VJ, LAZAR RM, SESHADRI S, TESTAI FD, VAN GAAL S, YAFFE K, WASIAK H, ZERNA C; AMERICAN HEART ASSOCIATION/AMERICAN STROKE A: Defining optimal brain health in adults: a presidential advisory from the American Heart Association/American Stroke Association. Stroke 48: e284-e303, 2017.

GRANSTAM SO, GRANSTAM E: Endothelin-induced changes in blood flow in STZ-diabetic and non-diabetic rats: relation to nitric oxide synthase and cyclooxygenase inhibition. J Physiol Sci 61: 497-505, 2011.

GROCHOWSKI C, LITAK J, KAMIENIAK P, MACIEJEWSKI R: Oxidative stress in cerebral small vessel disease. Role of reactive species. Free Radic Res 52: 1-13, 2018.

GUPTA YK, BRIYAL S, SHARMA U, JAGANNATHAN NR, GULATI A: Effect of endothelin antagonist (TAK-044) on cerebral ischemic volume, oxidative stress markers and neurobehavioral parameters in the middle cerebral artery occlusion model of stroke in rats. Life Sci 77: 15-27, 2005.

HARDIGAN T, ABDUL Y, ERGUL A: Linagliptin reduces effects of ET-1 and TLR2-mediated cerebrovascular hyperreactivity in diabetes. Life Sci 159: 90-96, 2016 a.

HARDIGAN T, WARD R, ERGUL A: Cerebrovascular complications of diabetes: focus on cognitive dysfunction. Clin Sci (Lond) 130: 1807-1822, 2016b.

HARDIGAN T, YASIR A, ABDELSAID M, COUCHA M, EL-SHAFFEY S, LI W, JOHNSON MH, ERGUL A: Linagliptin treatment improves cerebrovascular function and remodeling and restores reduced cerebral perfusion in Type 2 diabetes. Am J Physiol Regul Integr Comp Physiol 311: R466-R477, 2016c.

HARRIS AK, ELGEBALY MM, LI W, SACHIDANANDAM K, ERGUL A: Effect of chronic endothelin receptor antagonism on cerebrovascular function in type 2 diabetes. Am J Physiol Regul Integr Comp Physiol 294: R1213-R1219, 2008.

HARRIS AK, HUTCHINSON JR, SACHIDANANDAM K, JOHNSON MH, DORRANCE AM, STEPP DW, FAGAN SC, ERGUL A: Type 2 diabetes causes remodeling of cerebrovasculature via differential regulation of matrix metalloproteinases and collagen synthesis: role of endothelin-1. Diabetes 54: 2638-2644, 2005. 
HENRIKSSON M, STENMAN E, EDVINSSON L: Intracellular pathways involved in upregulation of vascular endothelin type B receptors in cerebral arteries of the rat. Stroke 34: 1479-1483, 2003.

HUNG VK, YEUNG PK, LAI AK, HO MC, LO AC, CHAN KC, WU EX, CHUNG SS, CHEUNG CW, CHUNG SK: Selective astrocytic endothelin-1 overexpression contributes to dementia associated with ischemic stroke by exaggerating astrocyte-derived amyloid secretion. J Cereb Blood Flow Metab 35: 1687-1696, 2015.

IADECOLA C, HACHINSKI V, ROSENBERG GA: Vascular cognitive impairment: introduction. Stroke 41: S127-S128, 2010.

IDF: Diabetes Atlas. International Diabetes Federation, Brussels, 2017.

IDRIS-KHODJA N, OUERD S, MIAN MO, GORNITSKY J, BARHOUMI T, PARADIS P, SCHIFFRIN EL: Endothelin-1 overexpression exaggerates diabetes-induced endothelial dysfunction by altering oxidative stress. Am J Hypertens 29: 1245-1251, 2016.

JO WK, LAW AC, CHUNG SK: The neglected co-star in the dementia drama: the putative roles of astrocytes in the pathogeneses of major neurocognitive disorders. Mol Psychiatry 19: 159-167, 2014.

KALLAKURI S, KREIPKE CW, ROSSI N, RAFOLS JA, PETROV T: Spatial alterations in endothelin receptor expression are temporally associated with the altered microcirculation after brain trauma. Neurol Res 29: 362-368, 2007.

KELLY-COBBS AI, ELGEBALY MM, LI W, ERGUL A: Pressure-independent cerebrovascular remodelling and changes in myogenic reactivity in diabetic Goto-Kakizaki rat in response to glycaemic control. Acta Physiol (Oxf) 203: 245-251, 2011a.

KELLY-COBBS AI, HARRIS AK, ELGEBALY MM, LI W, SACHIDANANDAM K, PORTIK-DOBOS V, JOHNSON M, ERGUL A: Endothelial endothelin B receptor-mediated prevention of cerebrovascular remodeling is attenuated in diabetes because of up-regulation of smooth muscle endothelin receptors. J Pharmacol Exp Ther 337: 9-15, 2011 b.

KELLY-COBBS AI, PRAKASH R, COUCHA M, KNIGHT RA, LI W, OGBI SN, JOHNSON M, ERGUL A: Cerebral myogenic reactivity and blood flow in type 2 diabetic rats: role of peroxynitrite in hypoxia-mediated loss of myogenic tone. J Pharmacol Exp Ther 342: 407-415, 2012.

LEUNG JW, CHUNG SS, CHUNG SK: Endothelial endothelin-1 over-expression using receptor tyrosine kinase tie-1 promoter leads to more severe vascular permeability and blood brain barrier breakdown after transient middle cerebral artery occlusion. Brain Res 1266: 121-129, 2009.

LI Q, PARK K, LI C, RASK-MADSEN C, MIMA A, QI W, MIZUTANI K, HUANG P, KING GL: Induction of vascular insulin resistance and endothelin-1 expression and acceleration of atherosclerosis by the overexpression of protein kinase C-beta isoform in the endothelium. Circ Res 113: 418-427, 2013.

LI W, PRAKASH R, KELLY-COBBS AI, OGBI S, KOZAK A, EL-REMESSY AB, SCHREIHOFER DA, FAGAN SC, ERGUL A: Adaptive cerebral neovascularization in a model of type 2 diabetes: relevance to focal cerebral ischemia. Diabetes 59: 228-235, 2010.

LI W, SACHIDANANDAM K, ERGUL A: Comparison of selective versus dual endothelin receptor antagonism on cerebrovascular dysfunction in diabetes. Neurol Res 33: 185-191, 2011.

MANEA SA, TODIRITA A, MANEA A: High glucose-induced increased expression of endothelin-1 in human endothelial cells is mediated by activated CCAAT/enhancer-binding proteins. PLoS One 8: e84170, 2013.

MATSUMOTO T, YOSHIYAMA S, KOBAYASHI T, KAMATA K: Mechanisms underlying enhanced contractile response to endothelin-1 in diabetic rat basilar artery. Peptides 25: 1985-1994, 2004.

MATSUO Y, MIHARA S, NINOMIYA M, FUJIMOTO M: Protective effect of endothelin type A receptor antagonist on brain edema and injury after transient middle cerebral artery occlusion in rats. Stroke 32: 2143-2148, 2001.

MAYHAN WG, ARRICK DM: Tetrahydrobiopterin rescues impaired responses of cerebral resistance arterioles during type 1 diabetes. Diab Vasc Dis Res 14: 33-39, 2017.

MAYHAN WG, ARRICK DM, PATEL KP, SUN H: Exercise training normalizes impaired NOS-dependent responses of cerebral arterioles in type 1 diabetic rats. Am J Physiol Heart Circ Physiol 300: H1013-H1020, 2011.

MISHRA A, NEWMAN EA: Inhibition of inducible nitric oxide synthase reverses the loss of functional hyperemia in diabetic retinopathy. Glia 58: 1996-2004, 2010. 
MOHEET A, MANGIA S, SEAQUIST ER: Impact of diabetes on cognitive function and brain structure. Ann N Y Acad Sci 1353: 60-71, 2015.

MURAKOSHI N, MIYAUCHI T, KAKINUMA Y, OHUCHI T, GOTO K, YANAGISAWA M, YAMAGUCHI I: Vascular endothelin-B receptor system in vivo plays a favorable inhibitory role in vascular remodeling after injury revealed by endothelin-B receptor-knockout mice. Circulation 106: 1991-1998, 2002.

NIEDOWICZ DM, REEVES VL, PLATT TL, KOHLER K, BECKETT TL, POWELL DK, LEE TL, SEXTON TR, SONG ES, BREWER LD, LATIMER CS, KRANER SD, LARSON KL, OZCAN S, NORRIS CM, HERSH LB, PORTER NM, WILCOCK DM, MURPHY MP: Obesity and diabetes cause cognitive dysfunction in the absence of accelerated beta-amyloid deposition in a novel murine model of mixed or vascular dementia. Acta Neuropathol Commun 2: 64, 2014.

PALMER J, LOVE S: Endothelin receptor antagonists: potential in Alzheimer's disease. Pharmacol Res 63: 525-531, 2011.

PALMER JC, BARKER R, KEHOE PG, LOVE S: Endothelin-1 is elevated in Alzheimer's disease and upregulated by amyloid-beta. J Alzheimers Dis 29: 853-861, 2012.

PALMER JC, TAYLER HM, LOVE S: Endothelin-converting enzyme-1 activity, endothelin-1 production, and free radical-dependent vasoconstriction in Alzheimer's disease. J Alzheimers Dis 36: 577-587, 2013.

PAPADOPOULOS P, ONGALI B, HAMEL E: Selective in vivo antagonism of endothelin receptors in transforming growth factor-beta1 transgenic mice that mimic the vascular pathology of Alzheimer's disease. Can J Physiol Pharmacol 88: 652-660, 2010.

PRAKASH R, JOHNSON M, FAGAN SC, ERGUL A: Cerebral neovascularization and remodeling patterns in two different models of type 2 diabetes. PLoS One 8: e56264, 2013a.

PRAKASH R, LI W, QU Z, JOHNSON MA, FAGAN SC, ERGUL A: Vascularization pattern after ischemic stroke is different in control versus diabetic rats: relevance to stroke recovery. Stroke 44: 2875-2882, 2013b.

PRAKASH R, SOMANATH PR, EL-REMESSY AB, KELLY-COBBS A, STERN JE, DORE-DUFFY P, JOHNSON M, FAGAN SC, ERGUL A: Enhanced cerebral but not peripheral angiogenesis in the Goto-Kakizaki model of type 2 diabetes involves VEGF and peroxynitrite signaling. Diabetes 61: 1533-1542, 2012.

QU Z, LI W, PRAKASH R, FAGAN S, ERGUL A: Diet-induced diabetes impairs neovascularization and functional recovery after ischemic stroke. Stroke 45: A169, 2014.

RIEDERER P, KORCZYN AD, ALI SS, BAJENARU O, CHOI MS, CHOPP M, DERMANOVIC-DOBROTA V, GRUNBLATT E, JELLINGER KA, KAMAL MA, KAMAL W, LESZEK J, SHELDRICK-MICHEL TM, MUSHTAQ G, MEGLIC B, NATOVICH R, PIRTOSEK Z, RAKUSA M, SALKOVIC-PETRISIC M, SCHMIDT R, SCHMITT A, SRIDHAR GR, VECSEI L, WOJSZEL ZB, YAMAN H, ZHANG ZG, CUKIERMAN-YAFFE T: The diabetic brain and cognition. J Neural Transm (Vienna) 124: 1431-1454, 2017.

ROSANO L, SPINELLA F, BAGNATO A: Endothelin 1 in cancer: biological implications and therapeutic opportunities. Nat Rev Cancer 13: 637-651, 2013.

SACHIDANANDAM K, HARRIS A, HUTCHINSON J, ERGUL A: Microvascular versus macrovascular dysfunction in type 2 diabetes: differences in contractile responses to endothelin-1. Exp Biol Med (Maywood) 231: 10161021, 2006.

SIMO R, CIUDIN A, SIMO-SERVAT O, HERNANDEZ C: Cognitive impairment and dementia: a new emerging complication of type 2 diabetes - the diabetologist's perspective. Acta Diabetol 54: 417-424, 2017.

SINGH G, SHARMA B, JAGGI AS, SINGH N: Efficacy of bosentan, a dual ETA and ETB endothelin receptor antagonist, in experimental diabetes induced vascular endothelial dysfunction and associated dementia in rats. Pharmacol Biochem Behav 124: 27-35, 2014.

SINGH M, PRAKASH A: Possible role of endothelin receptor against hyperhomocysteinemia and beta-amyloid induced AD type of vascular dementia in rats. Brain Res Bull 133: 31-41, 2017.

SINGH P, GUPTA S, SHARMA B: Antagonism of endothelin (ETA and ETB) receptors during renovascular hypertension-induced vascular dementia improves cognition. Curr Neurovasc Res 13: 219-229, 2016.

SPINELLA F, CAPRARA V, GARRAFA E, DI CASTRO V, ROSANO L, NATALI PG, BAGNATO A: Endothelin axis induces metalloproteinase activation and invasiveness in human lymphatic endothelial cells. Can J Physiol Pharmacol 88: 782-787, 2010. 
SPRAY S, JOHANSSON SE, RADZIWON-BALICKA A, HAANES KA, WARFVINGE K, POVLSEN GK, KELLY PAT, EDVINSSON L: Enhanced contractility of intraparenchymal arterioles after global cerebral ischaemia in rat - new insights into the development of delayed cerebral hypoperfusion. Acta Physiol (Oxf) 220: 417-431, 2017.

STENMAN E, MALMSJO M, UDDMAN E, GIDO G, WIELOCH T, EDVINSSON L: Cerebral ischemia upregulates vascular endothelin ETB receptors in rat. Stroke 33: 2311-2316, 2002.

STILES MC, SEAQUIST ER: Cerebral structural and functional changes in type 1 diabetes. Minerva Med 101: 105-114, 2010.

TAKAHASHI K, OHBA K, KANEKO K: Ubiquitous expression and multiple functions of biologically active peptides. Peptides 72: 184-191, 2015.

TONG XK, HAMEL E: Simvastatin restored vascular reactivity, endothelial function and reduced string vessel pathology in a mouse model of cerebrovascular disease. J Cereb Blood Flow Metab 35: 512-520, 2015.

VETRI F, QI M, XU H, OBERHOLZER J, PAISANSATHAN C: Impairment of neurovascular coupling in Type 1 Diabetes Mellitus in rats is prevented by pancreatic islet transplantation and reversed by a semi-selective PKC inhibitor. Brain Res 1655: 48-54, 2017.

VETRI F, XU H, PAISANSATHAN C, PELLIGRINO DA: Impairment of neurovascular coupling in type 1 diabetes mellitus in rats is linked to PKC modulation of $\mathrm{BK}(\mathrm{Ca})$ and Kir channels. Am J Physiol Heart Circ Physiol 302: H1274-H1284, 2012.

WARD R, ERGUL A: Relationship of endothelin-1 and NLRP3 inflammasome activation in HT22 hippocampal cells in diabetes. Life Sci 159: 97-103, 2016.

WU Y, FENG B, CHEN S, ZUO Y, CHAKRABARTI S: Glucose-induced endothelin-1 expression is regulated by ERK5 in the endothelial cells and retina of diabetic rats. Can J Physiol Pharmacol 88: 607-615, 2010.

YAMASHITA K, KATAOKA Y, SAKURAI-YAMASHITA Y, SHIGEMATSU K, HIMENO A, NIWA M, TANIYAMA K: Involvement of glial endothelin/nitric oxide in delayed neuronal death of rat hippocampus after transient forebrain ischemia. Cell Mol Neurobiol 20: 541-551, 2000.

YASIR A, HARDIGAN T, ERGUL A: Diabetes-mediated middle cerebral artery remodeling is restored by linagliptin: interaction with the vascular smooth muscle cell endothelin system. Life Sci 159: 76-82, 2016.

YEUNG PK, LO AC, LEUNG JW, CHUNG SS, CHUNG SK: Targeted overexpression of endothelin-1 in astrocytes leads to more severe cytotoxic brain edema and higher mortality. J Cereb Blood Flow Metab 29: 1891-1902, 2009.

ZHANG RL, ZHANG C, ZHANG L, ROBERTS C, LU M, KAPKE A, CUI Y, NINOMIYA M, NAGAFUJI T, ALBALA B, ZHANG ZG, CHOPP M: Synergistic effect of an endothelin type A receptor antagonist, S-0139, with rtPA on the neuroprotection after embolic stroke. Stroke 39: 2830-2836, 2008. 